\title{
PENGARUH JENIS PELARUT TERHADAP KANDUNGAN TOTAL FENOLIK, AKTIFITAS ANTIOKSIDAN DAN TOKSISITAS EKSTRAK BUAH CIPLUKAN (Physalis angulata L)
}

\section{EFFECT OF SOLVENT ON TOTAL PHENOLICS CONTENT, ANTIOXIDANT ACTIVITY AND TOXICITY OF CIPLUKAN FRUIT (Physalis angulata L.)}

\author{
Wahidiyanti Putri Julianti ${ }^{1}$, Yusep Ikrawan ${ }^{1}$, Ade Chandra Iwansyah ${ }^{2}$ \\ ${ }^{1}$ Teknologi Pangan, Universitas Pasundan, Bandung \\ 2Pusat Penelitian Teknologi Tepat Guna, Lembaga Ilmu Pengetahuan Indonesia (LIPI), \\ Jl. KS Tubun No. 5 Subang 41213, Telp (0260) 411478/ 411239 Jawa Barat \\ e-mail: wahidiyantip@gmail.com; chandra.iwansyah@gmail.com
}

Diterima : 28-03-2019

Direvisi : 11-04-2019

Disetujui : 21-05-2019

\begin{abstract}
ABSTRAK
Di Indonesia, produk herbal telah digunakan sebagian besar masyarakat untuk menjaga kesehatan. Tanaman ciplukan merupakan salah satu kearifan lokal yang dipercaya dapat menjaga dan mengobati berbagai penyakit, seperti Diabetes mellitus dan memiliki potensi sebagai pangan fungsional. Ciplukan mengandung komponen bioaktif, dimana proses ekstraksi dan penggunaan jenis pelarut memainkan peranan penting. Tujuan dari penelitian ini adalah untuk mempelajari pengaruh jenis pelarut terhadap kandungan total fenolik, aktifitas antioksidan dan toksisitas ekstrak buah ciplukan (Physalis angulata $\mathrm{L}$.). Desain eksperimental menggunakan rancangan acak lengkap (RAL) dengan menggunakan 3 pelarut yang berbeda, yaitu: etanol $70 \%\left(a_{1}\right)$, etil asetat $\left(a_{2}\right)$, dan $n$-heksana $\left(a_{3}\right)$, dengan 6 replikasi. Kandungan total fenolik, total flavonoid, aktifitas antioksidan (metode DPPH), dan toksisitas (Metode Brine Shrimp Lethality Test) ekstrak buah ciplukan diteliti. Hasil penelitian menunjukkan bahwa ekstrak etanol buah ciplukan $\left(a_{1}\right)$ memiliki kandungan total fenolik tertinggi $(140,50 \mathrm{mg} \mathrm{GAE} / \mathrm{g}$ ekstrak) dan total flavonoid(100,46 mg QE/g) diikuti oleh ekstrak etil asetat buah ciplukan(a $\mathrm{a}_{2}$ > ekstrak n-heksana buah ciplukan $\left(\mathrm{a}_{3}\right)$. Aktifitas antioksidan menunjukkan $a_{1}$ memiliki IC $_{50}$ terendah $(321,02 \mu \mathrm{g} / \mathrm{mL})$, memiliki aktifitas antioksidan tertinggi, dibandingkan $\mathrm{a}_{2}$ dan $\mathrm{a}_{3}$. Uji toksisitas menunjukkan bahwa nilai LC 50 ekstrak etanol buah ciplukan $\left(a_{1}\right)(886,1 \mu \mathrm{g} / \mathrm{mL})$ bersifat sitotoksik dibandingkan $a_{2}$ dan $a_{3}$. Penelitian ini menyimpulkan bahwa jenis pelarut yang digunakan dalam mengekstrak buah ciplukan dapat mempengaruhi kandungan total fenolik, aktifitas antioksidan dan toksisitas.
\end{abstract}

Kata kunci : aktifitas antioksidan, ciplukan, Physalis angulata, fitokimia, toksisitas.

\section{ABSTRACT}

In Indonesia, most people have used herbal products to maintain their health. Ciplukan plant is one of the local wisdom that is believed to be able to retain and treat various diseases, such as Diabetes mellitus its has potential as a functional food. Ciplukan contains bioactive components, where the extraction process and the use of solvent types play an important role. This study aims to determine the effect of solvent on total phenolics, antioxidant activities and toxicity of ciplukan (Physalis angulata L.) fruit. The experimental design used a completely randomized design (CRD) with three different solvents, namely: 70\% ethanol ( $\left.a_{1}\right)$, ethyl acetate ( $\left.a_{2}\right)$, and $n$-hexane ( $\left.a_{3}\right)$, six replications. Total phenolic content, total flavonoids, antioxidant activity (DPPH method), and toxicity (Method of Brine Shrimp Lethality Test) of mature ciplukan fruit extract were analyzed. The results showed that the ethanol extract of ciplukan fruit ( $a_{1}$ ) had the highest total phenolic content (140.50 mg GAE / g extract) and total flavonoids $(100.46 \mathrm{mg} Q E / g)$ followed by $a_{2}>a_{3}$. Antioxidant activity showed that a 1 had the lowest IC $50(321.02 \mu \mathrm{g} / \mathrm{mL})$, and had the highest antioxidant activity, compared to $a_{2}$ and $a_{3}$. Based on toxicity test, $L C_{50}$ value of ethanolic extract of ciplukan $\left(a_{1}\right)(886,1 \mu \mathrm{g} / \mathrm{mL})$ as cytotoxic. This study

70 Wahidiyanti Putri Julianti, Yusep Ikrawan, Ade Chandra Iwansyah Pengaruh Jenis Pelarut Terhadap Kandungan Total Fenolik, Aktifitas Antioksidan dan Toksisitas Ekstrak Buah Ciplukan (Physalis angulata L) 
can conclude that the type of solvent affects the total phenolics, antioxidant activitiesand toxicity of ciplukan fruit extract.

Keywords : antioxidant activity, ciplukan, Physalis angulata, phytochemical, toxicity.

\section{PENDAHULUAN}

I ndonesia merupakan negara dengan keanekaragaman hayati terbesar ke-2 di dunia yang terdiri dari tumbuhan tropis dan biota laut. Sebanyak 2.500 dari 7.000 jenis tumbuhan merupakan tanaman obat (Kemendag RI, 2014).Menurut Ekor (2014), penggunaan produk herbal mengalami peningkatan selama 3 dekade terakhir. Sebanyak $80 \%$ masyarakat dunia sudah menggunakan produk herbal untuk menjaga kesehatan mereka. Maka dari itu, saat ini banyak berkembang produk herbal untuk dikonsumsi oleh masyarakat.

Penelitian pangan fungsional berbasis herbal terkait penyakit tidak menular (PTM), khususnya Diabetes melitus (DM) sedang banyak diteliti dalam satu dekade ini. Menurut Riset Kesehatan Dasar Tahun 2013, prevalensi penderita DM mengalami peningkatan dari 1,1\% (2007) menjadi 2,1\% (2013) (Kemenkes RI, 2013). Melihat fenomena tersebut dan potensi dari keanekaragaman hayati di Indonesia, membuat banyak penelitian mengenai pengembangan produk pangan fungsional berbasis kearifan lokal. Salah satunya adalah tanaman ciplukan (Physalis angulata L.).

Ciplukan, famili Solanaceae, merupakan tanaman liar yang dipercaya secara turun temurun di Indonesia sebagai obat anti kencing manis. Menurut penelitian Baedowi yang dikutip oleh Latifah et al. (2014), didapatkan informasi bahwa ekstrak daun ciplukan memiliki aktifitas hiperglikemi secara in vivo pada hewan mencit. Hal tersebut tidak terlepas adanya aktifitas biologi yang berasal dari senyawa bioaktif pada tanaman ciplukan.

Fitokimia merupakan senyawa hasil metabolisme sekunder tanaman (metabolit sekunder). Sebagai senyawa aktif, fitokimia memiliki sifat toksik pada pemberian dengan dosis kuat pada manusia. Sehingga diperlukan uji toksisitas. Uji toksisitas adalah suatu uji untuk mendeteksi efek toksik suatu zat pada sistem biologi dan untuk memperoleh data dosis-respon yang khas dari sediaan uji (BPOM RI, 2014). Salah satu metode awal yang sering digunakan untuk mengamati toksisitas ekstrak dari tanaman adalah Brine Shrimp Lethality Test (BSLT).

Ekstraksi merupakan proses pemisahan bagian aktif tanaman atau jaringan hewan yang aktif dari komponen inaktif atau inert dengan menggunakan pelarut tertentu sesuai dengan prosedur ekstraksi standar (Handa et al., 2008). Ekstraksi juga sering digunakan untuk memisahkan senyawa metabolit sekunder pada bagian tanaman. Proses ekstraksi perlu memperhatikan jenis senyawa yang diinginkan, kelarutan dan kepolaran dari pelarut yang digunakan. Agar senyawa yang diinginkan dapat diekstraksi secara optimal, ekstraksi biasanya menggunakan berbagai jenis pelarut dengan polaritas berbeda. Hal ini bertujuan untuk mengekstrak senyawa metabolit sekunder (Lisdawati et al., 2006). Dengan menggunakan pelarut yang berbeda kelarutannya, diharapkan dapat dipelajari bagaimana pengaruh jenis pelarut terhadap kandungan total fenolik, aktifitas antioksidan dan toksisitas dari ekstrak buah ciplukan.

\section{METODE PENELITIAN}

\section{Bahan dan Alat}

Bahan-bahan yang digunakan pada penelitian ini, yaitu bagian tanaman ciplukan (Physalis angulata L.) berupa buah muda, kuncup, batang, dan buah matang yang diperoleh dari daerah Desa Rawalele, Kecamatan Dawuan, Kabupaten Subang-Jawa Barat; etanol 70\%, etil asetat, dan n-heksan, aquadest, larutan $\mathrm{FeCl}_{3} 1 \%$, larutan asam asetat glacial, larutan 
asam sulfat, serbuk $\mathrm{Mg}, \mathrm{HCl}$ pekat, $\mathrm{HCl} 2 \mathrm{~N}$, pereaksi Bouchardart ( $\mathrm{KI}$ dan $\mathrm{HgCl}_{2}$ ), pereaksi Meyer (KI dan bismuth (III) nitrat), dietil eter, $\mathrm{H}_{2} \mathrm{SO}_{4}$ pekat, $\mathrm{CH}_{3} \mathrm{COOH}$ anhidrat, asam galat, larutan sodium carbonate $\left(\mathrm{Na}_{2} \mathrm{CO}_{3}\right) 2 \%$, larutan folin cioceltaeu, larutan alumunium klorida $\left(\mathrm{AlCl}_{3}\right)$, kuersetin, 1,1-dipheny-2-pikrylhydrazyl (DPPH), metanol, telur larva udang kering (Artemia salina Leach), dan air laut.

Alat-alat yang digunakan pada penelitian ini diantaranya neraca analitik, botol timbang, erlenmeyer $500 \mathrm{~mL}$ dan $350 \mathrm{~mL}$, corong, kertas saring kasar, penguap vakum berputar, pengering rak, dan labu penguap. Alat-alat yang digunakan untuk analisis diantaranya neraca analitik, mikropipet ukuran $1.000 \mu \mathrm{L}$ dan 10-200 $\mu \mathrm{L}$, tabung reaksi, labu ukur $100 \mathrm{~mL}$ dan 10 $\mathrm{mL}$, spektrofotometer (Shimadzu $囚 \mathrm{UV}-1800$ ), kuvet, vial, botol air mineral 1,5 L, dan aerator.

\section{Penelitian pendahuluan}

Penelitian pendahuluan yang dilakukan yaitu skrining fitokimia dari berbagai bagian tanaman ciplukan diantaranya buah muda, kuncup, batang, dan buah matang. Keempat bagian tanaman ciplukan tersebut semula dilakukan pencucian untuk membersihkan sisa kotoran yang menempel. Pengeringan dilakukan menggunakanpengering rakpada suhu $45^{\circ} \mathrm{C}$ selama 42 jam. Bagian tanaman kering kemudian dihaluskan menggunakan chopper (Gambar 1).

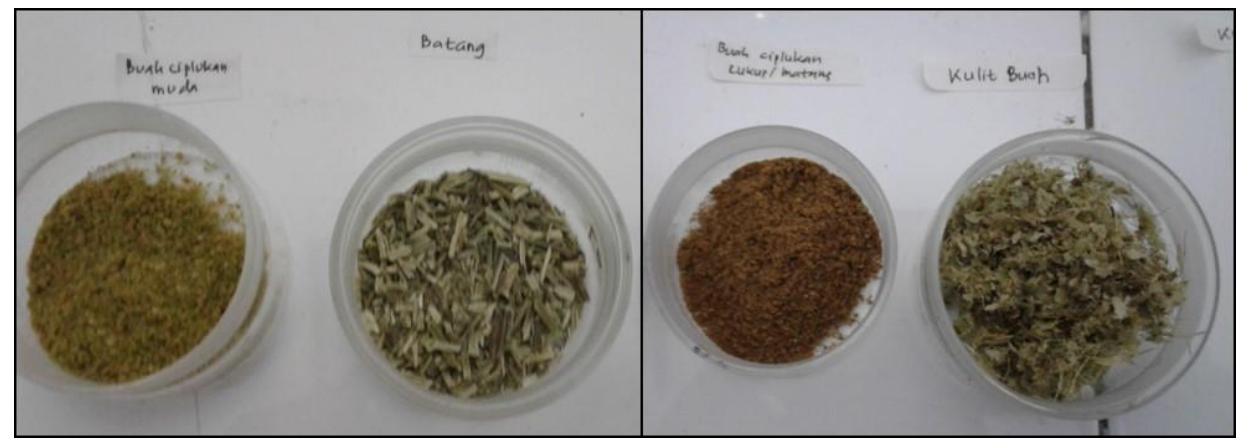

Gambar 1. Bagian tanaman ciplukan yang telah dikeringkan

Masing-masing serbuk halus kemudian diekstraksi secara maserasi selama 3x24 jam menggunakan pelarut etanol $70 \%$ dengan perbandingan serbuk:pelarut $=1: 10(\mathrm{~b} / \mathrm{v})$ dan selama itu dilakukan pergantian pelarut yang sama dengan jumlah yang sama. Kemudian ekstrak yang didapat diuapkan pelarutnya menggunakan evaporator sehingga didapatkan ekstrak kering. Masing-masing ekstrak kemudian dilakukan skrining fitokimia yang meliputi:

\section{Pengujian tanin dan glikosida (Edrah et al., 2016)}

Sebanyak 0,5 gram ekstrak dalam tabung reaksi ditambahkan $20 \mathrm{~mL}$ aquadest dan dipanaskan selama 5 menit, lalu disaring. Filtrat $(10 \mathrm{~mL})$ kemudianditambahkan beberapa tetes $\mathrm{FeCl}_{3} 1 \%$. Adanya tanin ditandai dengan terbentuknya warna hijau violet. Sedangkan untuk glikosida, sebanyak $5 \mathrm{~mL}$ filtrat ditambahkan 1 tetes $\mathrm{FeCl}_{3}, 2 \mathrm{~mL}$ asam asetat glasial, dan $1 \mathrm{~mL}$ asam sulfat. Adanya glikosida ditandai dengan adanya cincin cokelat atau cincin ungu.

\section{Pengujian saponin dan flavonoid (Edrah et al., 2016)}

Sebanyak 2 gram ekstrak ditambahkan $20 \mathrm{~mL}$ air dan dipanaskan selama 5 menit kemudian disaring. Sebanyak $10 \mathrm{~mL}$ filtrat diambil dan ditambahkan $5 \mathrm{~mL}$ air kemudian kocok hingga berbuih. Adanya saponin ditandai dengan adanya buih yang stabil. Sedangkan untuk 
flavonoid, $10 \mathrm{~mL}$ filtrat diambil dan ditambahkan $0,1 \mathrm{~g}$ serbuk $\mathrm{Mg}$ dan 10 tetes $\mathrm{HCl}$ pekat. Positif flavonoid ditandai dengan timbulnya warna jingga kemerahan.

\section{Pengujian alkaloid (Wullur et al., 2018)}

Sebanyak 0,5 g ekstrak dilarutkan dalam $1 \mathrm{~mL} \mathrm{HCl} 2 \mathrm{~N}$ dan $9 \mathrm{~mL}$ aquadest kemudian dipanaskan. Setelah itu didinginkan dan disaring sehingga diperoleh filtrat. Filtrat diteteskan pada plat tetes. Setiap plat kemudian diteteskan reagen Meyer yang positif ditandai dengan perubahan warna menjadi putih, dan reagen bouchardart yang positif ditandai dengan perubahan warna menjadi cokelat kehitaman.

\section{Pengujian terpenoid dan steroid (Pratiwi, 2009)}

Sebanyak 0.1 gram ekstrak ditambahkan $5 \mathrm{~mL}$ dietil eter, kemudian dipanaskan hingga kering. Residu yang dihasilkan ditambahkan 1 tetes $\mathrm{H}_{2} \mathrm{SO}_{4}$ dan 3 tetes $\mathrm{CH}_{3} \mathrm{COOH}$ anhidrat. Positif terpenoid ditandai dengan warna merah ungu dan positif steroid ditandai dengan warna hijau atau biru.

\section{Penelitian Utama}

Penelitian utama merupakan penelitian lanjutan dari penelitian pendahuluan, untuk mengetahui pengaruh jenis pelarut terhadap karakteristik fitokimia dan toksisitas ekstrak ciplukan. Metode yang digunakan adalah metode eksperimental dengan Rancangan Acak Lengkap (RAL) yang terdiri dari satu faktor (a) yaitu jenis pelarut yang terdiri dari 3 taraf, yaitu $a_{1}$ etanol $70 \%, a_{2}$ etil asetat, $a_{3} n$-heksan dengan 6 kali ulangan sehingga didapatkan 18 satuan percobaan.

Serbuk buah ciplukan, sebagai bagian terpilih dari penelitian pendahuluan, diekstraksi secara maserasi selama 3×24 jam menggunakan pelarut etanol 70\%, etil asetat, dan n-heksan dengan perbandingan serbuk:pelarut $1: 10(\mathrm{~b} / \mathrm{v})$ dan selama itu dilakukan pergantian pelarut yang sama dengan jumlah yang sama. Kemudian ekstrak yang didapat diuapkan pelarutnya menggunakan evaporator sehingga didapatkan ekstrak kering. Selanjutnya masing-masing ekstrak dilakukan pengujian diantaranya:

\section{Rendemen}

Rendemen ekstrak dihitung dengan perbandingan ekstrak ciplukan yang diperoleh (mg) dengan berat sampel ciplukan (mg) dikalikan $100 \%$.

\section{Total Fenolik (Iwansyah et al., 2016, dengan modifikasi)}

Sebanyak 50 mg ekstrak ditimbang dan dilarutkan dengan aquadest dalam labu takar $10 \mathrm{~mL}$. Ekstrak buah ciplukan $(0,1 \mathrm{~mL})$ ditambahkanakuades $(2,8 \mathrm{~mL})$ dan natrium karbonat $(2 \%, 2 \mathrm{~mL})$ dalam test tube dan didiamkan selama 4 menit. Setelah didiamkan, kemudian ditambahkan 0,1 mL larutan Folin-Cioceltaeu dan didiamkan selama 30 menit. Lalu diukur absorbansi menggunakan spektrofotometer UV-Vis pada panjang gelombang $760 \mathrm{~nm}$. Total fenol ekstrak dinyatakan sebagai milligram $(\mathrm{mg})$ asam galat ekuivalen per gram bobot ekstrak (GAE mg/g ekstrak buah). Sebagai standar digunakan asam galat.

\section{Total flavonoid (Muaja et al., 2013, dengan modifikasi)}

Sebanyak $50 \mathrm{mg}$ ekstrak ditimbang dan dilarutkan dengan aquadest dalam labu takar $10 \mathrm{~mL}$. Ekstak buah ciplukan $(1 \mathrm{~mL})$ ditambahkan larutan alumunium klorida $(2 \%, 2 \mathrm{~mL})$, yang telah dilarutkan dalam methanolterlebih dahulu, dihomogenisasi, kemudian diukur absorbansinya menggunakan spektrofotometer UV-Vis pada panjang gelombang $415 \mathrm{~nm}$. Kuersetin digunakan sebagai standar.Kandungan total flavonoid dinyatakan sebagai ekuivalen kuersetin dalam $\mathrm{mg} / \mathrm{g}$ ekstrak. 


\section{Aktifitas antioksidan (Iwansyah et al., 2016, dengan modifikasi)}

Ekstrak ciplukan (50 mg)ditambahkan akuades $(50 \mathrm{~mL})$ ke dalam labu takar $50 \mathrm{~mL}$, dihomogenisasisehingga diperoleh larutan induk sebesar $1.000 \mu \mathrm{g} / \mathrm{mL}$. Dari larutan induk tersebut dilakukan pengenceran ke dalam beberapa kosentrasi $0 ; 25 ; 50 ; 100 ; 200 ;$ dan 500 $\mu \mathrm{g} / \mathrm{mL}$. Diambil sampel sebanyak $1 \mathrm{~mL}$ dari tiap konsentrasi ke dalam test tube dan ditambahkan $3 \mathrm{~mL}$ larutan DPPH metanolik 0,004\% kemudian didiamkan selama 30 menit di area gelap. Aktifitas antioksidan ( IC $_{50}$ ) diukur menggunakan spektrofotometer UV-Vis pada panjang gelombang $515 \mathrm{~nm}$ terhadap larutan DPPH tanpa sampel (blanko).

\section{Toksisitas (Sukandar et al., 2015, dengan modifikasi)}

Sebanyak 25 mg ekstrak buah ciplukanmatang ditimbang dan dilarutkandengan larutan metanol:akuades dengan rasio $1: 1(\mathrm{v} / \mathrm{v})$. Ekstrak buah ciplukan matang $(1 \mathrm{~mL})$ kemudian ditambahkan air laut $(25 \mathrm{~mL})$ dalam labu takar $25 \mathrm{~mL}$, sehingga didapatkan larutan induk sebesar $1.000 \mu \mathrm{g} / \mathrm{mL}$. Dari larutan induk tersebut dilakukan pengenceran ke dalam beberapa konsentrasi $0 ; 12,5 ; 25 ; 100 ; 500$; dan $1.000 \mu \mathrm{g} / \mathrm{mL}$ dalam air laut. Sampel (2 mL) dari setiap konsentrasi, dimasukan ke dalam tabung reaksi dan ditambahkan 10 larva udang berusia 24 jam, kemudian ditambahkan air laut sampai volume $5 \mathrm{~mL}$. Sampel uji dilakukan penyimpanan 24 jam, kemudian dilakukan pengamatan terhadap sampel uji. Parameter pengamatan yaitu dengan perhitungan larva hidup dan larva mati.

\section{Analisis data}

Data disajikan dalam bentuk rataan \pm standar deviasi. Uji normalitasdata dilakukanterlebih dahulu, kemudian dianalisis menggunakan analisis sidik ragam (ANOVA). Uji lanjut perbandingan berganda Duncan dilakukan untuk mengetahui perbedaan nyata rataan antar variabel dengan galat $(a=5 \%)$. Analisis statistik dilakukan dengan menggunakan program Microsoft Excel 2013.

\section{HASIL DAN PEMBAHASAN}

\section{Skrining fitokimia}

Skrining fitokimia dilakukan sebagai penelitian pendahuluan untuk mengetahui potensi fitokimia pada bagian tanaman ciplukan secara kualitatif. Hasil analisis dari skrining fitokimia dapat dilihat pada Tabel 1.

Tabel 1. Skrining fitokimia pada berbagai bagian tanaman ciplukan

\begin{tabular}{|c|c|c|c|c|c|c|}
\hline \multirow{2}{*}{$\begin{array}{c}\text { Bagian } \\
\text { tanaman }\end{array}$} & \multicolumn{6}{|c|}{ Analisis Kualitatif } \\
\cline { 2 - 7 } & Tanin & Saponin & Glikosida & Flavonoid & Alkaloid & $\begin{array}{c}\text { Terpenoid \& } \\
\text { Steroid }\end{array}$ \\
\hline Buah muda & + & - & + & + & - & ++ \\
\hline Kuncup & +++ & - & ++ & ++ & - & ++ \\
\hline Batang & ++ & + & - & + & - & ++ \\
\hline $\begin{array}{c}\text { Buah } \\
\text { matang }\end{array}$ & +++ & - & +++ & ++ & - & +++ \\
\hline
\end{tabular}

Keterangan: (+) ada, semakin banyak jumlah, semakin kuat kandungannya (secara kualitatif); (-) tidak ada.

Tabel 1 menunjukkan bahwa ekstrak buah muda, kuncup, batang, dan buah matang mengandung tanin, flavonoid, terpenoid dan steroid. Berdasarkan uji saponin menunjukkan hanya bagian batang yang mengandung saponin. Uji glikosida menunjukkan seluruh bagian tanaman yang mengandung glikosida kecuali pada bagian batang. Sementara itu, tidak terdapat alkaloid di seluruh sampel ekstrak bagian tanaman ciplukan.Berdasarkan hasil 
penelitian pendahuluan, maka dapat disimpulkan bahwa buah ciplukan matang digunakan untuk penelitian utama atau selanjutnya.

\section{Penelitian Utama}

\section{Rendemen}

Pada proses ekstraksi, pemilihan jenis pelarut dan senyawa yang akan diekstrak merupakan hal penting yang harus diperhatikan terutama rendemen. Pengaruh jenis pelarut terhadap rendemen ekstrak buah ciplukan matang disajikan pada Gambar 2.

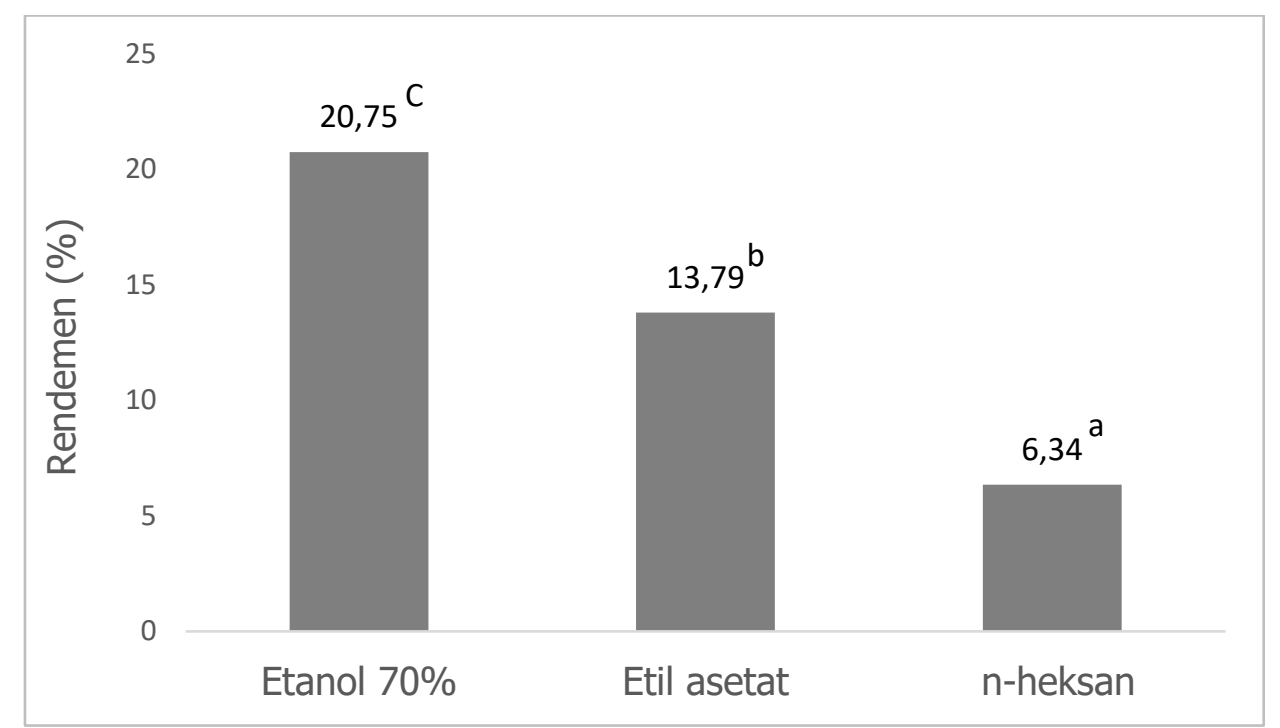

Gambar 2. Rendemen ekstrak buah ciplukan matang. $c>b>a$, huruf yang berbeda menunjukan berbeda nyata ( $a=5 \%)$.

Gambar 2 menunjukkan bahwa jenis pelarut berpengaruh nyata terhadap rendemen, total fenol, total flavonoid, aktifitas antioksidan, dan toksisitas dari ekstrak buah matang ciplukan $(P<0,05)$. Berdasarkan uji lanjut Duncan menunjukan bahwa ekstrak etanol $70 \%$ $\left(a_{1}\right)$ memiliki rata-rata rendemen lebih tinggi $(20,75 \%)$ dibandingkan ekstrak etil asetat $\left(a_{2}\right)$ danekstrak $n$-heksan $\left(a_{3}\right)$. Hal tersebut dikarenakan pelarut etanol memiliki polaritas yang tinggi sehingga dapat menghasilkan rendemen lebih banyak dibandingkan pelarut lainnya.Menurut Azis et al. (2014), pelarut etanol memiliki dua sisi yang terdiri dari gugus $\mathrm{OH}$ yang bersifat polar dan gugus $\mathrm{CH}_{2} \mathrm{CH}_{3}$ yang bersifat non polar sehingga dapat mengekstrak senyawa aktif baik dari golongan polar maupun non polar.

\section{Total fenolik, total flavonoid dan aktifitas antioksidan}

Pengaruh jenis pelarut terhadap total fenolik, total flavonoid dan aktifitas antioksidan ekstrak buah ciplukan matang dapat dilihat pada Tabel 2.

Tabel 2. Total fenolik, total flavonoid dan aktifitas antioksidan ekstrak buah ciplukan

\begin{tabular}{|l|c|c|c|}
\hline \multicolumn{1}{|c|}{ Sampel } & $\begin{array}{c}\text { Total Fenol } \\
\text { (mg GAE/g ekstrak) }\end{array}$ & $\begin{array}{c}\text { Total Flavonoid } \\
(\mathrm{mg} \mathrm{QE} / \mathrm{g} \text { ekstrak })\end{array}$ & $\begin{array}{c}\text { Aktifitas Antioksidan } \\
\left(\mathrm{IC} \mathrm{C}_{50}: \mu \mathrm{g} / \mathrm{mL} \text { ) }\right.\end{array}$ \\
\hline Ekstrak etanol 70\% & $140,50 \pm 38,63^{\mathrm{c}}$ & $100,46 \pm 1,06^{\mathrm{c}}$ & $321,02 \pm 13,60^{\mathrm{a}}$ \\
\hline Ekstrak etil asetat & $32,77 \pm 7,19^{\mathrm{b}}$ & $91,19 \pm 2,28^{\mathrm{b}}$ & $369,97 \pm 20,34^{\mathrm{b}}$ \\
\hline Ekstrak n-heksan & $5,27 \pm 3,58^{\mathrm{a}}$ & $0,9 \pm 0,25^{\mathrm{a}}$ & $1.165,66 \pm 49,55^{\mathrm{c}}$ \\
\hline
\end{tabular}

Data merupakan rataan $\pm S D(n=6) . c>b>a$, huruf yang berbeda pada satu kolom menunjukan berbeda nyata $(a=5 \%)$. 
Tabel 2 menunjukkan bahwa jenis pelarut mempengaruhi nilai rataan total fenolik dari ekstrak buah ciplukan matang $(P<0,05)$. Uji lanjut Duncan yang dilakukan menunjukan bahwa ekstrak etanol $70 \%\left(a_{1}\right)$ memiliki rata-rata kandungan total fenol lebih tinggi $(140,50 \mathrm{mg}$ $\mathrm{GAE} / \mathrm{g}$ ) dibandingkan ekstrak etil asetat $\left(\mathrm{a}_{2}\right)$ dan ekstrak n-heksan $\left(\mathrm{a}_{3}\right)$. Hal ini dikarenakan senyawa fenolik dalam tumbuhan sangat larut dalam pelarut etanol.

Table 2 menunjukkan juga bahwa nilai total flavonoid pada ekstrak buah ciplukan matang dipengeruhi oleh jenis pelarut yang digunakan $(P<0,05)$. Berdasarkan uji lanjut Duncan, Ekstrak etanol $70 \%\left(\mathrm{a}_{1}\right)$ buah ciplukan matang memiliki rata-rata kandungan total flavonoid tertinggi $(100,46 \mathrm{mg} \mathrm{QE} / \mathrm{g})$ dibandingkan ekstrak etil asetat $\left(\mathrm{a}_{2}\right)>$ ekstrak $\mathrm{n}$-heksan $\left(a_{3}\right)$. Hal ini dikarenakan senyawa flavonoid yang bersifat polar akan larut dalam pelarut polar. Senyawa flavonoid yang terdapat pada buah ciplukan matang akan banyak terlarut dalam pelarut etanol $70 \%$. Hasil ini sejalan dengan prinsip polarisasi, dimana suatu senyawa akan larut dalam pelarut yang mempunyai kepolaran yang sama (Suryani et al., 2015). Menurut Saxena et al. (2011) etanol mempunyai polaritas yang mendekati polaritas fenol dan flavonoid pada tanaman sehingga memiliki kemampuan sebagai pelarut dalam mengekstrak tanaman.

Metode DPPH ( $\mathrm{IC}_{50}$ ) biasa digunakan dalam menghitung aktifitas antioksidan dari suatu ekstrak. IC ${ }_{50}$ menyatakan konsentrasi dimana ekstrak dapat menguraikan $50 \%$ radikal bebas yang pada pengujian ini yaitu DPPH. Berdasarkan Tabel 2, jenis pelarut berpengaruh terhadap aktifitas antioksidan ekstrak buah ciplukan matang $(P<0,05)$. Uji lanjut Duncan menunjukan bahwa ekstrak etanol $70 \%\left(a_{1}\right)$ memiliki nilai rata-rata IC $_{50}$ terendah $(321,02 \mu \mathrm{g} / \mathrm{mL})$ dibandingkan ekstrak etil asetat $\left(a_{2}\right)<$ ekstrak n-heksan $\left(a_{3}\right)$. Hal ini menunjukkan bahwa ekstrak etanol $70 \%$ dari buah ciplukan matang memiliki aktifitas antioksidan tertinggi dibandingkan $a_{2}$ dan $a_{3}$. Hasil ini disebabkan karena kandungan senyawa fitokimia terutama flavonoid yang memiliki aktifitas antioksidan lebih banyak terekstrak pada pelarut polar. Semakin banyak senyawa fitokimia yang memiliki aktifitas antioksidan tersebut terekstrak, maka aktifitas antioksidannya semakin tinggi.

\section{Hubungan antara total fenol dengan aktifitas antioksidan}

Kandungan fenolik dapat dikaitkan dengan aktifitas radikal bebas. Senyawa fenolik memiliki kemampuan untuk mengikat radikal bebas (Maisuthisakul et al., 2008; Iwansyah et al., 2016).

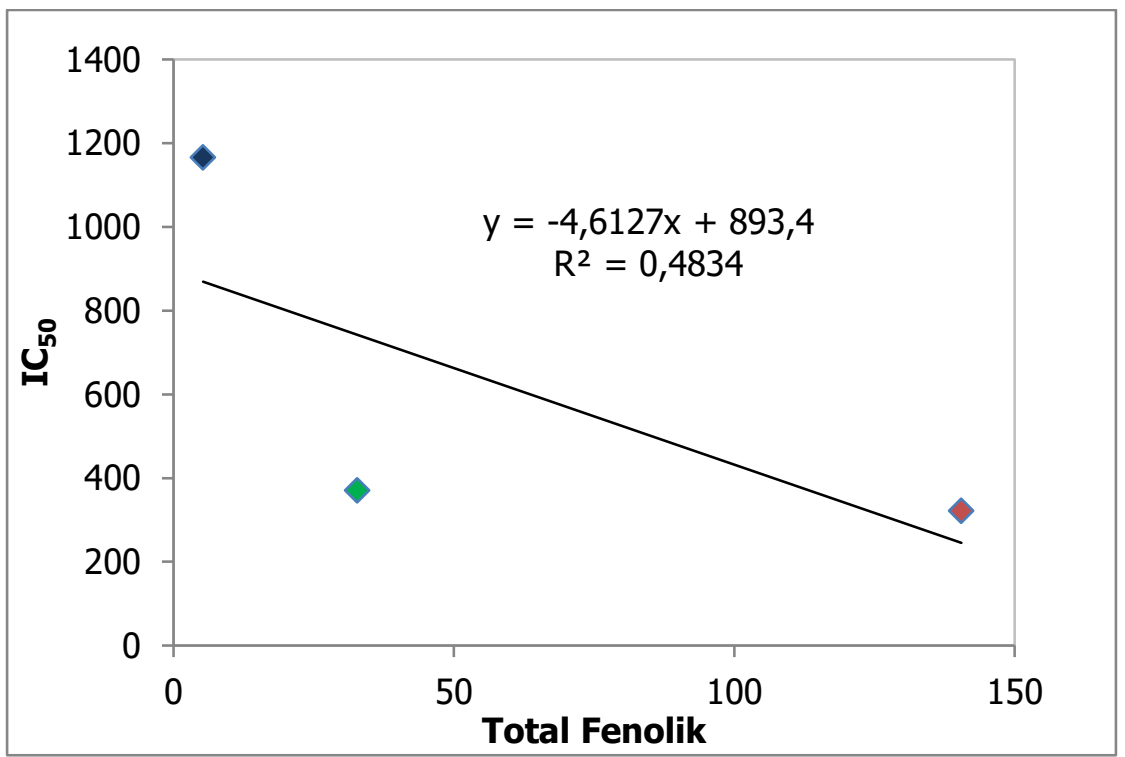

Gambar 3. Grafik hubungan kandungan total fenolik dengan aktifitas antioksidan 
Gambar 3 menunjukkan korelasi antara total fenolik dengan aktifitas antioksidan buah ciplukan matang memiliki hubungan yang rendah $\left(R^{2}: 0,483\right)$. Hal ini dikarenakan jenis pelarut menentukan senyawa fenolik yang terekstrak dan tidak semua senyawa fenolik memiliki aktifitas antioksidan. Pelarut etanol $70 \%$ memiliki kelarutan terhadap senyawa fenolik yang tinggi karena tergolong pelarut polar. Namun terdapat kecenderungan semakin tinggi kandungan total fenolik, maka semakin rendah nilai IC $_{50}$ nya (semakin tinggi aktifitas antioksidan). Penelitian Maisuthisakul et al., (2008) dan Iwansyah et al., (2016) melaporkan bahwa terdapat hubungan yang erat antara total fenolik dengan aktifitas antioksidan pada berbagai tanaman. Gambar 3 menunjukkan juga bahwa $48 \%$ antioksidan pada buah ciplukan berasal dari senyawa fenolik dan $52 \%$ sisanya berasal dari metabolit sekunder lainnya seperti karotenoid, vitamin, dan sebagainya.

\section{Toksisitas (BSLT assay)}

Uji toksisitas adalah suatu uji untuk mendeteksi efek toksik suatu zat pada sistem biologi dan untuk memperoleh data dosis-respon yang khas dari sediaan uji. Menurut Layyina (2014), tingkat toksisitas ditentukan dengan mengevaluasi nilai konsentrasi mematikan $50 \%$ (LC 50 ). Nilai $\mathrm{LC}_{50}$ adalah konsentrasi suatu zat yang dinyatakan dalam $\mu \mathrm{g} / \mathrm{mL}$ media uji yang dapat menyebabkan 50 \% kematian pada binatang percobaan dari suatu kelompok spesies setelah binatang percobaan tersebut terpapar dalam waktu tertentu (Cahyono, 2004). Salah satu metode untuk uji toksisitas adalah Brine Shrimp Lethality Test (BSLT). Pengaruh jenis pelarut terhadap toksisitas ekstrak buah ciplukan matang disajikan pada Tabel 3.

Tabel 3. Pengaruh pelarut terhadap toksisitas ekstrak buah ciplukan matang

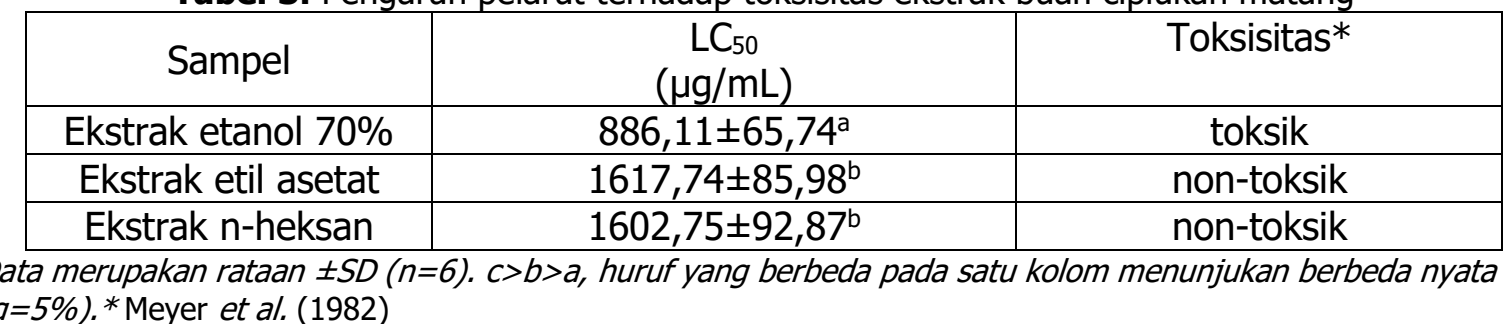

Tabel 3 menunjukkan jenis pelarut mempengaruhi toksisitas ekstrak buah ciplukan matang $(P<0,05)$. Uji lanjut Duncan menunjukan bahwa ekstrak etanol $70 \%\left(\mathrm{a}_{1}\right)$ memiliki nilai rata-rata toksisitas lebih tinggi $(886,11 \mu \mathrm{g} / \mathrm{mL})$ dibandingkan ekstrak n-heksan $\left(a_{3}\right)$ dan ekstrak etil asetat $\left(\mathrm{a}_{2}\right)$. Hal ini disebabkan karena kandungan metabolit sekunder yang menyebabkan toksik terhadap larva udang lebih banyak larut dalam pelarut etanol $70 \%$ sehingga mempengaruhi mortalitas dari ekstrak.

Hasil penelitian ini sejalan dengan pernyataan Setyowati dan Cahyanto (2016) yang melaporkan semakin tinggi kandungan metabolit sekunder yang terekstrak pada saat proses ekstraksi menggunakan pelarut tertentu, maka semakin toksik suatu bahan. Selain itu, aktifitas toksik ekstrak dari daun kersen timbul karena kandungan senyawa metabolit sekunder yang dimiliki tanaman tersebut.

\section{KESIMPULAN}

Berdasarkan hasil penelitian maka diperoleh kesimpulan bahwa jenis pelarut berpengaruh terhadap karakteristik fitokimia dan toksisitas dari ekstrak ciplukan (Physalis angulata L.) dan pelarut yang terpilih adalah etanol $70 \%$. 


\section{UCAPAN TERIMA KASIH}

Penulis mengucapkan terima kasih kepada Kementerian Riset dan Teknologi dan Pendidikan Tinggi (Kemenristekdikti) - Republik Indonesia atas dukungan finansial berupa Hibah Insinas Flagship LIPI 2018 (No. 20/P/PRL_LIPI/INSINAS-1/III/2018) dan Lembaga Ilmu Pengetahuan Indonesia atas dukungan akses dan teknis.

\section{DAFTAR PUSTAKA}

Azis, T., Febrizky, S., Mario, A.D. 2014.Pengaruh Jenis Pelarut terhadap Persen Yieldalkaloid dari Daun Salam India (Murraya koenighi). Palembang: Universitas Sriwijaya.

Badan Pengawas Obat dan Makanan (BPOM) RI. 2014. Peraturan Kepala Badan Pengawas Obat Dan Makanan Republik Indonesia Nomor 7 Tahun 2014 Tentang Pedoman Uji Toksisitas Nonklinik Secara In Vivo. Jakarta: Badan Pengawas Obat dan Makanan Republik Indonesia.

Cahyono, A.B.2004. Keselamatan Kerja Bahan Kimia di Industri. Yogyakarta: UGM Press.

Edrah, S.M., Aljenkawi, A., Omeman, A., Alafid, F. 2016. Qualitative and quantities analysis of phytochemicals of various extract for Ephedra altissima from Libya. Journal of Medicinal Plants Studies, 2016; 4(3): 119-121.

Ekor, M. 2014. The Growing Use of Herbal Medicines: Issues Relating to Adverse Reactions and Challenge Sinmonitoring Safety. Frontiers in Pharmacology,4:1-10.

Handa, S.S., Khanuja, S.P.S., Longo, G., Rakesh, D.D. 2008. Extraction Technology for Medicinal and Aromatic Plants. Trieste: ICS UNIDO.

Iwansyah, A.C., Damanik R.M., Kustiyah, L.,Hanafi, M. 2016. Relationship Between Antioxidant Properties and Nutritional Composition of Some Galactopoietics Herbs Used in Indonesia: A Comparative Study. International Journal of Pharmacy and Pharmaceutical Sciences, 8:236-243.

Kementerian Perdagangan (Kemendag) RI. 2014. Warta Ekspor Obat Herbal Tradisional. Jakarta: Kementerian Perdagangan Republik Indonesia.

Kementerian Kesehatan (Kemenkes) RI. 2013. Riset Kesehatan Dasar (Riskesdas). Jakarta: Kementerian Kesehatan Republik Indonesia.

Latifah, N., Hidayati, A.A., Yunas, S.R.,Sulistyorini, E. 2014. Ciplukan (Physalis angulata L.).Terdapat dalam: http://ccrc.farmasi.ugm.ac.id/?page_id=193. Diakses: 22 Maret 2018.

Layyina, H. 2014. Toksisitas Ekstrak Ciplukan (Physalis angulata) Berdasarkan Uji Letalitas Larva Udang. Bogor: Institut Pertanian Bogor.

Lisdawati, V., Wiryowidagdo, S., Kardono, L.B.S. 2006. Bioasai In Vitro Antikanker Terhadap Sel Leukemia L1210 dari Berbagai Fraksi Esktrak Daging Buah dan Kulit Biji Mahkota Dewa (Phaleria macrocarpa). Jurnal Bahan Alam Indonesia,5:303-309.

Maisuthisakul, P., Pasuk, S., Ritthiruangdej, P. 2008.Relationship between antioxidant properties and chemical composition of some Thai plants. Journal of Food Composition and Analysis, 21:229-40.

Meyer, B., Ferrigni, N., Putnam, J., Jacobsen, L., Nichols, D., McLaughlin, J. 1982. Brine shrimp: a convenient general bioassay for active plant constituents. Journal of Medicinal Plant Research, 45, 31-34.

Muaja, A.D.,Koleangan, H.S.J., Runtuwene, M.R.J. 2013.Uji Toksisitas dengan Metode BSLT dan Analisis Kandungan Fitokimia Ekstrak Daun Soyogik (Saurauia bracteosa DC) dengan Metode Soxhletasi. Jurnal MIPA UNSRAT Online, 2:115-118.

Pratiwi, E.2009. Aktifitas Antioksidan Ekstrak Dan Fraksi Aktif Temukunci (Boesenbergia pandurata Roxb.). Bogor: IPB. 
Saxena, D.K., Sharma, S.K., Shambi, S.S. 2011. Comparative extraction of Cottonseed Oil by n-hexane and etanol. Journal of Engineering and Applied Science, 6(1): 84-89.

Setyowati, W.A.E., dan Cahyanto, M.A.S. 2016. Kandungan Kimia Dan Uji Aktifitas Toksik Menggunakan Metode BSLT (Brine Shrimp Lethality Test) dari Ekstrak Daun Kersen (Muntingia calabura). Jurnal Kimia dan Pendidikan Kimia, 1:41-47.

Sukandar, D., Hermanto, S., Lestari, E. 2015. Uji Toksisitas Ekstrak Daun Pandan Wangi (Pandanus amaryllifolius Roxb.) Dengan Metode Brine Shrimp Lethality Test (BSLT). Jakarta: UIN Syarif Hidayatullah.

Suryani, N.C., Permana, D.G.M., Jambe, A. 2015. Pengaruh Jenis Pelarut Terhadap Kandungan Total Flavonoid dan Aktifitas Antioksidan Ekstrak Daun Matoa (Pometia pinnata), Bali: Universitas Udayana.

Wullur, A.C., Schaduw, J., Wardhani, A.N.K. 2018. Identifikasi Alkaloid pada Daun Sirsak (Annona muricata L.). Manado: Politeknik Kesehatan Kemenkes Manado. 